\title{
山崎豊子『大地の子』論
}

陸一心の人物像をめぐって

Chuhui TANG(唐楚輝 : PhD Student, Kansai University Graduate School of Letters)

tangsoki1218@gmail.com

(日本)関西大学大学院文学研究科国語国文学専修博士後期課程。日本近現代文学、日中比較文学、山崎豊子作品 研究。『「二つの祖国の歴史的真実性について』(札幌：『札幌大学総合研究』第10号, 札幌大学総合研究所. 2018)な ど。

\section{Japan-China Relations and Conflicting Identities in The Son of Earth by Toyoko Yamasaki : Focusing on the Character of Yixin Lu}

This paper examines how Yixin Liu, the main character of Toyoko Yamasaki's The Son of Earth, was formed. First, Yamasaki's interview records are investigated to identify who she chose as a model for Yixin. Second, this paper clarifies how Yamasaki deployed the real experiences of war orphans and the conventions of modern Chinese literature to develop the narrative structure of the novel. Then, the features of the main character are analyzed, with a focus on how this final persona evolved from the original draft to the published version. This analysis involves a consideration of the history of post-war Japan-China relations, as they relate to two issues that were neglected in previous studies: Yixin Liu's long-cherished wish to become fully Chinese, and his perception of his motherland Japan. Based on the analysis of the end of the novel in some of the previous research, this paper discusses the reasons why Yixin eventually becomes 'the son of the earth', along with the war orphans who were affected by drastic changes in Japan-China relations.

Ultimately Yixin realizes he was brought up in China and that he is a "son of the earth of China". Therefore, he firmly establishes his identity as Chinese, and is freed from the conflict between his identities.

Keywords War Orphan(戦争孤児), Identity(アイデンティティ), Japan-China Relationship (日中関係), Modern Chinese Literary Works(現代中国 文学作品), Interview Records(取材記録) 


\section{1 はじめに}

山崎豊子は1957年、処女作『暖策』を上梓し、作家としてデビューした。翌年、『花の 机』を刊行し、第39回直木賞を受けた。その後、相次いで『華麗なる一族』、白い巨塔』 などの長編小説を発表し、大いに脚光を浴びた。彼女の作品の売り上げは累計で四千万 部であり、その数は凡そ日本の全人口の三分の一に相当する。それ故に、「国民的な小 説家」と称される1。

だが、山崎の作品は通俗的大河小説と見なされ、「文学的な研究や本格的な批評の対 象となることはめったにない」2。しかし、近年以来、そういう状況が徐々に変わって きた。代表作の一つである『大地の子』は日本のみならず、中国の研究者にも注目され る。

『大地の子』は1987年から1991年まで『月刊 文藝春秋』に連載された長編小説である。 1991年、単行本『大地の子 $($ 上・中・下)』(文藝春秋)が出版され、また、1994年に文庫本 として『大地の子 $($ 一 $)$ (四)』(文春文庫)が発行された。本作品は2008年に刊行された『山 崎豊子全集』(新潮社)第19、20巻に収載されている。

本作品は残留孤児の陸一心を主人公として、1945年8月、ソ連軍が旧満州に攻め込ん だ時から、1985年9月、中日合作プロジェクトの宝華製鉄所(現実の宝山製鉄所)の高炉火 入れまでの約40年間の半生を語ったものである。

先行研究を顧みれば、主人公像 ${ }^{3} 、$ 剽窃疑惑 4 、作中で現れた作者の反戦意識 5 、作品 における中国の表象 6 、物語の展開などの課題をめぐる作品論は枚挙に遑がないと分か る。

そして、主人公像に関する先行研究に着目したい。何故ならば、主人公陸一心の人物

1 大澤真幸『山崎豊子と〈男〉たち』(新潮新書, 2017), p.3.

2 大澤真幸「山崎豊子(だけ)が、なぜ男』を描くことができたのか」(『山崎豊子、スペシャル・ガイドブック』. 新潮社, 2015), p.199.

3 主人公像に関する先行論として、王晶・王亭亭「山崎豊子筆下的中国東北遺孤一以『大地之子』為中心」(『日本 研究』2015年第1号, 遼寧大学日本研究所, 2015.4, pp.84-89)、単援朝「日中女性作家が描いた中国残留孤児 像：山崎豊子『大地の子』と厳歌苓『小姨多鶴』を読む」(『跨境/日本語文学研究』第6号, 高麗大学校GLOBAL日 本研究院,2018.6,pp.33-48)、大澤真幸『大地の子」になる』『山崎豊子と〈男〉たち』新潮新書, 2017, pp.157 173)などが挙げられる。

4 剽窃疑惑に関する先行論として、鵜飼清「『大地の子』と中国残留孤児一フィクションとノンフィクションの 狭間を考える」(「山崎豊子問題小説の研究一社会派『国民作家』の作られ方」(社会評論社, 2002), pp.93-116.

5 李瑞華 $『$ 『地の子』から見た山崎豊子の反戦・平和意識」『文化交渉：東アジア文化研究科院生論集』第7号, 関西大学大学院東アジア文化研究科, 2017.11), pp.185-200.

6 作中における中国表象に関する先行研究として、鮑同・姜毅然曰日本現代文学中的中国形象一以「大地之子」 為例一』(『語学習与研究』第3号, 対外経済貿易大学, 2012.6, pp116-123)、李青「日本人作家の見た中国一 『李香蘭 私の半生』と『大地の子』から一」(『松阪大学紀要』第10号, 松阪大学, 1992.7, pp.39-50)、劉迎「山崎 豊子『大地の子』にみる一九八 $○$ 年代の日中関係」(『岡山の記憶』第19号, 岡山・十五年戦争資料センター, 2017.7, pp.58-63)などが挙げられる。

7 物語の展開に関する論文として、森田喜郎「『大地の子』における『運命』の展開(上)一切り拓いた運命一」 (『文学研究』第83号, 日本文学研究会, 1996.6, pp.39-53)及び『大地の子』における『運命』の展開(下)一切り 拓いた運命一」(『文学研究』第84号, 日本文学研究会, 1996.12, pp.41-54)などが挙げられる。 
像に関して激しく論争されてきたからである。先行論は主として次の三つが挙げられ る。王晶、王亭亭(2015)は陸一心と妹の張玉花の境遇を互いに照らし合わせ、以下のよ うに分析した。

『大地の子』は陸一心の人生遍歴をめぐって、語られた戦争孤児の物語である。小 説は養父母の恩愛に恵まれ、高等教育を受けた陸一心という日本孤児像を作った。こ れに対して、童養媳 ${ }^{8} と し て 、$ 貧困な農村で牛馬のように使われた張玉花という孤児 像を描いた。陸一心は幸せな孤児というならば、張玉花は不幸な孤児の代表者であ る。(筆者訳 $)^{9}$

兄妹の運命に着眼し、同じく残留孤児であるが、二人の境遇は遥かに異なると指摘し た。さらに、新中国で、童養媳を引き取るという陃習が無くなった故に、張玉花の人間 像が現実離れしていると説いた。だが、陸一心の人間像については、詳しく分析しな かった。そのほか、中国残留孤児像のリアリティについて、単援朝(2018)は主人公の設 定に注目し、

狭き門だった工業大学を出て中央官庁のエリートとまでなった残留孤児は極めて 珍しい存在である。このように、作中の現実と実際の現実との間に落差があること は明らかである。それは山崎豊子が自分の中の残留孤児像を描き切るための工夫で あるとみていい ${ }^{10}$ 。

とし、高等教育を受け、入党し、エリートとなる主人公設定は現実とかなり離れ、作家 自身の理想的な孤児像を描いたと捉えた。だが、単氏は主人公が残留孤児から大地の子 となる経緯を詳細に検討しなかった。

そのほか、大澤真幸 (2017) は『大地の子』の主人公を前作『つの祖国』、『不毛地带』の 主人公と対比させ、「彼は、日本が敗戦した時に中国に残された戦争孤児だからだ。(中 略)陸一心は、山崎が造形した人物の中でも最も魅力的な『男』である。」 ${ }^{11}$ と評価した。 主人公の造形を肯定したが、主人公の心理描写、行動を深く掘り下げて考察することは しなかった。

また、先行論は、主人公の造形に関する重要な手掛かりに触れてこなかった。それ は作者の構想である。『大地の子』を書こうと決めた際、山崎は次のように、構想を述べ た。

8 将来、息子の嫁にするために幼い時から引き取って育てた女の子。童養媳を引き取ることは中国の以前の 陃習である。

9 王晶・王亭亭「山崎豊子筆下的中国東北遺孤一以『大地之子』為中心」(『日本研究』第 1 号, 遼寧大学日本研究所, 2015.4), p.86.

10 単援朝「日中女性作家が描いた中国残留孤児像：山崎豊子『大地の子』と厳歌苓『小姨多鶴』を読む」(『跨境/日 本語文学研究』第6号, 高麗大学校GLOBAL日本研究院, 2018.6), p.40.

11 大澤真幸『「大地の子」になる』山崎豊子と〈男〉たち』新潮新書, 2017), pp.161-162. 
『大地の子』は日本の戦争孤児だから書けたんです。陸一心だけを書くと戦争孤児 物語で、それだったら体験記のほうが血を流した分だけずっと迫力がある。戦争孤 児を何とか現代中国と結び付ける方法はないだろうか(中略)考えた末、日中合作プロ ジェクトの上海宝山製鉄所の建設につなげられないものだろうかと思いついたんで $\Phi^{12}$ 。

山崎はただ戦争孤児物語を書けば済むとは思っていなかった。何故ならば、多くの 戦争孤児体験記は既に出版されている。作家である以上、戦争孤児を題材とし、これま での体験記と異なる作品を書かなければならない。引用文の傍線部からは、戦争孤児を 日中関係と結ぼうとした山崎の着想が読み取れる。戦後の日中関係史を視野に入れ、主 人公像を造形しようと考えたのである。

そのほか、山崎は主人公が日本人なのに、何としても中国人となろうと考えた点に 注目した。何故、中国人の仲間入りをしたがるのか。先行研究は、その理由を分析した ことはない。確かに実際、日本に帰国せず、中国人として、中国に生き残った残留孤児 はいた。山崎はそのような残留孤児を主人公のモデルとして選定したと考えられる。だ が、先行論で、モデルを検討したことはない。また、主人公は母国に対し、どのように 考えたのか。先行研究は、その点をも論じたことはない。よって、本稿では、先行研究 を踏まえ、主人公のアイデンティティの分析を試みる。

そもそも、アイデンティティの意味は「ある程度安定した自己のイメージをもってい

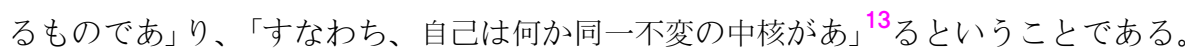
簡単に言えば、アイデンティティとは、「自分は何者だ」という自己認識である。陸一心 にとって、アイデンティティは「自分は日本人なのか、中国人なのか」という葛藤であ る。

張嵐(2011) は、残留孤児に取材し、彼らのアイデンティティを研究した。その結 果、残留孤児には、アイデンティティ・クライシスに囚われ、どの国の人間なのかと分 からない者と、中国と日本いず加に所属し、定着してきた者がいるという ${ }^{14}$ 。しか し、作品の結末で、主人公は「大地の子」と自称した。何故、最後、「大地の子」を自称し たのか。後文で、その理由を論じていく。

さて、「大地の子」の意味合いについて、単援朝、大澤真幸は自身の解釈を基に論じ た。だが、「大地の子」という言葉の出処を明らかにしたことはない。その出処を踏ま え、大地の子の含意を検討すべきだと思われる。

そこで、本稿では、従来の研究で言及されてこなかった問題点を取り上げ、戦後の 日中関係史を考察しながら、主人公像を再検討する。本論の流机は次のようになる。第

12 山崎豊子「伝えること一。それが生き残った私の使命です」(『SOPHIA』講談社, 1993.2), p.229.

13 辻平治郎『自己認識と他者認識』(北大路書房, 2003), p.9.

14 張嵐『『中国残留孤児』の社会学一日本と中国を生きる三世代のライフストーリ一」(青弓社, 2001), pp.173-191. 
2章で、作者の取材活動を調べ、如何なる人物をモデルとし、主人公を造り出したのか を明らかにする。また、どのような文献を引用し、ストーリーを作ったのかを論及す る。第3章では、主人公の心理描写と行動を辿りながら、主人公の中国人としてのアイ デンティティ意識と母国である日本に対する認識を検討する。第4章で、主人公はな ぜ、「地の子」と自称したのかを分析する。以上の分析を通し、主人公がどのように両 国に挟まれた中国残留孤児から、大地の子となったのかを考察する。

\section{2 陸一心のモデル}

主人公のモデルについて、秘書の野上孝子氏は取材を受けた際、「実際の戦争孤児の 中にそんな都合のいい人物が存在するはずがなく、粘土細工のように、主人公像を作っ ていくわけです」 ${ }^{15}$ と述べた。つまり、完全に都合のいい人間がいないので、複数の人 の生き様を「粘土」として、陸一心の人物造形に取り入れたのである。そのため、主人公 像を分析するには、いわゆる「粘土」を取り除き、人物設定における作者のオリジナリ ティを見つける必要がある。従って、本章で、作者は取材活動を通じて、人物設定にお いて、どのような素材を利用したのかを明らかにする。

1984年から、山崎は中国での3年間の取材活動を始めた。その取材の範囲はほぼ中国 全土に行き渡った ${ }^{16}$ 。そもそも、残留孤児は中国東北地方に在住していることが多 い17。残留孤児に対して取材をするだけなら、東北地方を中心に訪問すればよいが、山 崎は、中国全土に亘って取材を行った。そこからは、戦争孤児を現代中国と繋げようと いう作者の意困が読み取れる。

さて、取材活動で、山崎は如何なる人間を主人公のモデルとして、選び出したの か。筆者の調査によって、主人公のモデルと見做された人は以下のようになる。

15 朱琳「野上孝子氏インタビュー一山崎豊子と『大地の子』」(城西国際大学日本研究センタ一紀要』 8 号, 城西 国際大学日本研究センター, 2018.1), p.57.

16 後日談『大地の子」と私』(文春文庫，2003)及び野上孝子氏の回想録『山崎豊子先生の素顔』(文春文庫，2018） などの文献によれば、三年間(1984-1986)、山崎は北京、東北地方(潘陽、長春、ハルビン、勃利県、大連 など)、新疆、敦煌、西安、寧夏、内蒙古、重慶、武漢、上海、広州などへ取材をしに行った。

$17 「 『$ 中国残留孤児』の社会学」の238頁で、張嵐は『日本遺孤調査研究』(関亜新・張志坤.社会科学文献出版社, 2005)の調査を踏まえ、残留孤児が最も集中している地域が東北だと概説した。 
【表1】主人公のモデル

\begin{tabular}{|c|c|c|}
\hline モデル & シーン ${ }^{18}$ & 備考 \\
\hline 張永海 (偽名) & 「開拓団民逃亡」、「文革」、結末 & 中国に残留 \\
\hline 紅谷寅夫 $^{19}$ & 「開拓団民逃亡」(佐渡開拓団跡事件) & 普通の戦争孤览、帰国 \\
\hline 劉奔 ${ }^{20}$ & $\begin{array}{l}\text { なし(主に彼の養親の職業、及び養親との関係 } \\
\text { を参考した。) }\end{array}$ & 張永海と同様 \\
\hline 王同山、王書海 ${ }^{21}$ & 「長春戦役」 & 張永海と同様 \\
\hline 張賢亮 ${ }^{22}$ & 「文革」 & 中国人 \\
\hline 宝山製鉄所中国人通訳 ${ }^{23}$ & 「学生時代」、「宝華製鉄所建設」 & \\
\hline
\end{tabular}

【表1】のように、山崎は7人のモデルを選びだした。そして、彼らの人生遍歴を各 シーンのストーリーに取り込んだ。7人のモデルの中には、残留孤児だけではなく、中 国人もいる。なぜ、作者は複数の人間をモデルとして、選んだのか。『大地の子』は戦争 孤児を描いたものだけではなく、現代中国の様相をも表現した小説である。一人の取材 を通して描くだけでは、物語に深みがない。そこで、小説の内容を充実させるために、 複数の人間をもモデルとして選定した。ところで、ここで着目したいのは、張永海であ る。李徳純(2014)の文章で、彼の生い立ちが記されている。

1984年10月、山崎豊子は中国黒竜江省牡丹江の重油工場で働いた日本人孤児にイ ンタビューし、彼の経歴がドラマチックな色彩を帯びていることに気付いた。その 後、彼の経歴を手本として、小説の組み立てを作った。(筆者訳) ${ }^{24}$

18『大地の子』のストーリー構成によって、「開拓団民逃亡」、「長春戦役」、「学生時代」、「文革」、「宝華製鉄 所建設」、結末といら六つのシーンに分けられる。

19 山崎の取材日記によると、紅谷が佐渡開拓団事件で九死に一生を得たことが分かり、山崎は彼の体験の一 部を小説主人公に取り入れようと考えていたようだ。（山崎豊子『「大地の子」と私』(文春文庫，2003）， pp.46-47)

20 山崎の取材を受けた劉奔は自作の文章で、「『大地の子』の基本的人物設定は形式的な面からのみ言うと私 の状況に似ている。すなわち、主人公・陸一心の養父・陸徳志は、私の養父と同じくやはり田舎の小学校 教師だ(後略)」と述べた。(劉奔著・山口勇訳「中国残留孤児を真に理解しているのは誰か」『週刊金曜日』 6(48)，株式会社金曜日，1998.12, p.28)

21 当時、中国の雑誌記事「日本著名作家山崎豊子氏、長春へ取材に」によると、山崎豊子は国共内戦の長春戦 役を調査するために、三度長春に訪れたようだ。長春滞在期間、山崎は長春電機廠で働いた王同山、中国 科学院長春地理研究所で働いた王書海、及び彼らの養親に取材した。（国晏「日本著名作家山崎豊子来長採 訪」『社会科学戦線』1986年1期, 吉林省社会科学院, 1986.3, p.23)

22 山崎の秘書野上孝子の回想録によれば、中国反思文学の代表作家張賢亮は山崎豊子と面会したことがある という。(野上孝子『山崎豊子先生の素顔』文春文庫，2018，p.199）小説主人公の文革時期における境遇を張 賢亮の文革体験と照合すると、重なる点がみられる。そのことから、山崎は張氏の文革体験を主人公に取 り入れたと思われる。

23 山崎の秘書野上孝子の回想録によれば、宝山製鉄所の中国人通訳と巡り会ったという(野上孝子『山崎豊子 先生の素顔』文春文庫，2018，pp.186-187)。その通訳は大連工学院(現在の大連理工大学)出身で、日中の製 鉄所建設交渉に参加した。彼の経歴は主人公の大学、職場の設定と類似するので、山崎は彼の経験を小説 主人公に取り入れたと考えられる。 
また、後日談『大地の子」と私』の取材日記で、張永海の半生が次のように記録され た。彼はソ満の国境に近い開拓団出身である。1945年8月、ソ連軍が攻め込んだ祭、家 族と共に、逃亡した。牡丹江に到着した後、団民らの武装はソ連軍に解除された。その 頃、張氏は家族と離散し、中国人に貴われた。親切な養親に恵まれ、無事に成長し、黒 龍江の大学にも入学した。文革時期、出自が日本であることを理由に、迫害された。党 組織は「日本の無産階級の子供には侵略戦争の責任はない」と、張氏を庇った。だが、 「反革命分子」と見做され、辱められた。1983年、日本へ里帰りし、実父と再会した。実 父に永住帰国を勧められたが、中国人養親の恩愛を感じて、中国に戻った ${ }^{25}$ 。

取材日記の日付は李徳純の論文と同じく、1984年10月であり、取材対象も石油工場で 働いた戦争孤児だと分かる。さらに、注目したいのは、張永海は取材で、「私の民族、 血統は日本、忠誠を誓うのは中国だ」 ${ }^{26}$ と話した。山崎はそのようなアイデンティティ 意識を主人公に取り込んだと思われる。よって、張永海は小説主人公の主要なモデルと 考えられる。

そのほか、山崎はモデルの人生経歴を主人公に取り入れたばかりではなく、残留孤 児物語、中国現代文学作品の設定などの要素をも参考にした。初版本収録の際、作品の 末尾において、106冊の参考文献が記された ${ }^{27}$ 。参考文献を調查した結果、12冊の書籍が 主人公造形と直接の関係があることが分かった。

【表2】引用された参考文献とオリジナリティ

\begin{tabular}{|c|c|c|}
\hline シーン & 参考文献 & オリジナリティ \\
\hline 「開拓団民逃亡」 & $\begin{array}{l}\text { 『シャオハイの満州』(江成常 } \\
\text { 夫) } 28\end{array}$ & \multirow{4}{*}{$\begin{array}{l}\text { 日本人としての記憶を哀失したため、主人 } \\
\text { 公は中国人になろうと決意した。差別され } \\
\text { たが、中国人となる信念を諦めない。 }\end{array}$} \\
\hline 「長春戦役」 & 『卡子』(遠藤誉) 29 & \\
\hline \multirow[t]{2}{*}{ 「学生時代」 } & 『語文』(中国の国語教科書) 30 & \\
\hline & 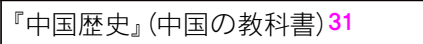 & \\
\hline \multirow[t]{3}{*}{ 「文革」 } & 『中国残留孤児問題』(中野謙二) 32 & \multirow{3}{*}{$\begin{array}{l}\text { 文革直後、冤罪を晴らした主人公は、日本 } \\
\text { へ出張した際、母国を改めて認識した。 }\end{array}$} \\
\hline & 『中国文学最新事情』(竹内実) 33 & \\
\hline & 『土牢情話』(張賢亮) 34 & \\
\hline \multirow[t]{2}{*}{ 「宝華製鉄所建設」 } & 『不沈的大地』(羅来勇) 35 & \multirow{3}{*}{$\begin{array}{l}\text { (1)主人公は入党したが、中国人として認め } \\
\text { られない。(2)「大地の子」と自称し、日本人 } \\
\text { の父と別れた。 }\end{array}$} \\
\hline & 『天雲山伝奇』(魯彦周) 36 & \\
\hline 結末 & \begin{tabular}{|l} 
『長江漢詩紀行』(渡部英喜) \\
『実像の中国』(岡田臣弘) 37
\end{tabular} & \\
\hline
\end{tabular}

24 李徳純「不譲須眉的日本女作家」(『中日関係史研究』第1期, 中国中日関係史学会, 2014.3), p.75.

25 山崎豊子「『大地の子』と私」(文春文庫, 2003), pp.36-44.

26 同上, p.44.

27 参考文献の種類と数は次のようになる。(1)文革関係の文献：24冊、(2)現代中国の国情に関する文献：10 冊、(3)満洲開拓団、戦争孤児の関連文献：26冊、(4)紀行、生活類の書籍：10冊、(5)評伝：15冊、(6)中国現 代文学作品：15冊、(7)鉄鋼関係資料：6冊など。

28 江成常夫『シャオ八イの満州』(新潮文庫，1988)において、紅谷寅夫の佐渡開拓団跡事件体験が記載され 
【表2】にあげたこれら参考文献を山崎はどのように作品に取り入れたのか。一つ は、「開拓団民逃亡」のように、中国残留孤児体験記における歴史事実を作品に用いたこ とが指摘できる。もう一つは、『土牢情話』で主人公が牢獄に拘束されること、『天雲山 伝奇』で主人公が誣告されることなどの中国現代文学作品におけるプロットを借り、小 説の構成を組み立てること、及び読者に臨場感を与えるために、中国の教科書などの素 材を小道具として、小説の場面に書き込むようにしていると言える。

山崎はモデルの経歴と参考文献からの引用を寄せ集めて繋いだばかりではなく、独 創的な内容も書いた。【表2】のように、作品のオリジナリティは二つある。一つ目 は、陸一心は「戦争孤児」から「共産党員」となり、また「大地の子」となったという物語の 主軸である。もう一つは、陸一心は如何にして、母国日本を認識したのかということで ある。次章からは、これらの箇所を取り上げ、主人公像を分析していく。

\section{3 両国の間で挟まれた戦争孤児}

前章の検討を通じて、主人公の中国人となる宿願、及び日本に対する認識という人物 設定に関する作品のオリジナル性を明らかにした。本章では、その二つのオリジナリ

た。山崎は紅谷の命からがら生き残った経験(p.82 84)を主人公に取り込み、小説的に改編した。(『大地の 子』(一), 文春文庫，1996，pp.69-72）

$29 「$ 長春戦役」シーンにおいて、山崎は陸一心一家が「卡子」(軍の検問所)を脱出したプロット(『大地の子』 (一)，四章「爸々」）を書いた時、『卡子』(第三章「絶望都市・長春」)を参考にしたと思われる。それで、『卡 子』の著者遠藤誉は山崎が盗作したことを以て、訴訟を提起した。裁判の結果、盜作は成立せず、山崎は 勝訴した。(『朝日新聞』2001年3月27日朝刊)

30 『大地の子』(一)の四章において、主人公小学校時代の国語授業の場面が描かれた。「永遠に毛沢東に従おう」 という詩歌が引用された。山崎は中国の小学校国語教科書(北京師範大学中文系普通教育改革小組編『語文』, 人民教育出版社)を抜粋したと思われる。だが、詩歌の最初の出典は郭沫若・周揚編『紅旗歌謡』(作家出版 社，1961)に収録された「歌唱毛沢東(毛沢東を謳歌しよう)」(p.4)である。

31『大地の子』（一)の五章において、主人公中学校時代の歴史授業の場面は描かれた。授業の内容は九・一八 事変 (満州事変)である。出典は中国の高校歴史教科書『中国歴史』(劉恵吾等編『中国歴史』人民教育出版社, 1957)の44 45頁である。

32『大地の子』(一)の一章で、文革の際、陸一心が日本人であるが故に、「スパイ」という冤罪を被り、批判さ れた場面が描かれた。それは、山崎が『中国残留孤児問題』(中野謙治『中国残留孤児問題』情報企画出版, 1987)における「文革時の苦しみ」(pp.91-92)を参考にして描いたと考えられる。

33『中国文学最新事情』(竹内実・萩野脩二, サイマル出版会, 1987.2, pp.59-82)は中国反思文学の代表作家張賢 亮(主人公陸一心のモデルの一人)の生涯を記載した。

34『土牢情話』(初出：『十月』第1号, 北京出版社, 1981.1, pp.26-76)は張賢亮の自身の文革体験を題材にした作 品である。山崎はこの作品における一部のストーリーを『大地の子』に取り込んだと思われる。

35『不沈的大地』(再見、鮑爾斯先生』羅来勇, 解放軍文芸出版社, 1984, pp.45-81)で収録された)は上海宝山製 鉄所建設を背景とした小説である。山崎はこの作品を参考にし、自作のプロットを作ったと考えられる。

36『天雲山伝奇』において、主人公は無実の罪を着せられ、左遷された。主人公の元恋人は、主人公の冤罪を 晴らした。「宝華製鉄所建設」には、それと類似するストーリーの展開がみられる。

37 小説の結末で、主人公は日本人実父と共に長江の旅をした際、李白の「早発白帝城」を詠えた。小説におけ る漢詩の要素は、渡部英喜『長江漢詩紀行』(昭和堂, 2000)の「長江三峡」(pp.81-87)及び岡田臣弘『実像の中 国』(有斐閣選書, 1982) 
ティをめぐり、作品における主人公の言動と心理描写を巡りながら、同時代の日中関係 を考察し、主人公のアイデンティティ意識を検討する。

\section{1 中国人となる宿願}

まず、小説の始まりから検討する。作品は主人公の文革時期の体験を語り始める。文 革とは、中国で、1966年から、1976年まで続いた政治運動である。その際、元資産家、 元地主出身の人々はもちろん、知識人、さらに国家指導者にも、冤罪を被った人は大勢 いた。中国残留孤児は日本侵略者の末裔なので、被害を免れなかった ${ }^{38}$ 。従って、主人 公も例外なく、「日本帝国主義者の種」「スパイ」と見做される。次に示すのは、主人公 が文革に巻き込まれた場面である。

中山帽がふっ飛び、やや伸びすぎた髪が、額にかかっていたが、切れ長の眼 も、浅黒く引き締った皮膚の色も、周囲に居並ぶ中国人と何ら異るところはなかっ た。

「なぜ、素直に出てこなかったのだ」

「私を産んだのは日本人です、しかし私は中国人として育ち、生きて来ました、 党と国家への忠誠心にかけて、私は中国人以外の何ものでもありません」

(中略)「そうか、ではお前は何年何月に入党したのだ、党歴を云ってみろ!」

陸一心は口ごもった。その人間に一生、ついて回る档案(身上書)に日本人、とき されているために、入党申請は却下され続けて今日に至っている ${ }^{39} 。$

主人公の陸一心に関する三つの特徴が示唆されている。一つ目は、陸一心は戦争孤児 であるが、周りの中国人の外見と同じく、すでに中国人の群れに溶け込んでいるという ことである。二つ目は、彼は両親を日本人だと認めたが、「私は中国人以外の何もので もありません」と自称しているということである。つまり、張永海のように、中国人だ と自覚している。三つ目は、主人公は入党を熱望したが、出自が日本であるため、党員 となれないことである。入党については、後文で論じていく。

ここで、注意したいのは、二番目の特徵である。日本人なのに、主人公は中国人と 自称する。そもそも、これは前文で提起されたモデルの張永海のアイデンティティ意識 と重なる。このようなアイデンティティ意識は山崎が意図的に主人公に取り込んだ要素 だと考えられる。だが、主人公は何故、中国人になろうと思っていたのか。その理由 は、以下のようになる。

38 中野謙二『中国残留孤児問題』(情報企画出版, 1987), pp.91-94.ここで、文革時期、中国残留孤児の悲惨遭 遇が記される。

39 山崎豊子『大地の子』(一) (文春文庫, 1996), pp.22-23. 
一心は、これまで何度も、佐渡開拓団跡のソ連軍虐殺事件以前の生活を思い出そ うとしても、思い出せず、(中略)まさしく医学辞典に書かれているように、堪え難 い事件、あの虐殺事件の場面が大きな黒い幕のように前に塞がり、それ以前の記憶 は、ぷつりと途絶えてしまっている。

『記憶喪失』の一語が、一心の胸を鋭く抉ったが、中国人・陸一心として生きるた めには、その方がかえってよかったかも知れないと考えたのだった ${ }^{40}$ 。

1945年8月、陸一心は開拓団民と共に逃亡する途中、佐渡開拓団跡でソ連軍と遭遇し た。陸一心は戦火から九死に一生を得たが、あまりの恐怖ゆえに、一部の記憶を培失し た。その記憶は開拓団時代の生活、家族のこと、自分の日本名などである。こうして、 日本人としての記憶を既に失った陸一心は、中国人として生きることを決意する。

また、大連の大学に入学し、港に立ち、海の向こうにある母国を思った時、「望郷の 念に似た想いが胸を掠めたが、中国人、陸徳志の息子、陸一心として生きる決心はいさ さかも摇るがなかった」41。ここで、「陸徳志の息子」に着目したい。主人公は中国人陸 徳志に育てられたため、自分は中国人に違いないと思い込んでいる。「陸徳志の息子」と いう出自は、彼の中国人としてのアイデンティティ意識の根幹をなしている。

小説の中で、主人公が中国人となる理由は示された。ただし、戦後の日中関係を視野 に入れ、深く論じる必要がある。新中国成立後、日本は中国と公式的国交を結んでいな いとは言え、貿易関係及び中国滞在親族捜しなどの様々な民間交流を保っていた。だ が、1958年の長崎国旗事件により、貿易、さらには非公式に行われてきた民間交流が中 断された。

敗戦後の四五年から五八年ころまで、まず興安丸が、次いで白山丸が日本と中国 の間を往復して引揚者を運んだ。

(中略) (岸信介は)首相になると、米国の中国敵視政策に同調、五七年六月の台湾訪 問では、台湾政府の大陸反攻を支持する演説を行った。これが中国を硬化させた。

五八年五月、長崎市内のデパートで開かれていた中国品展示会場で、中国に反感 を抱く右翼が、会場に揚げてあった中国国旗を引きずり降ろした。警察はいったん 犯人を逮捕したものの「旗が破れていないので、器物毁棄に当るかどうか疑わしい」 と、䣋放した。国旗を、ただの器物として扱ったのである。

中国はこれを機に日中貿易を中断、親捜し運動や遺骨送還事業などの人道的交流 も打ち切られた(長崎国旗事件) ${ }^{42}$ 。

この事件によって、日本と中国の民間交流も途絶えた。そして、中国滞在の日本人帰 国事業も中止された。そのため、残留孤児は帰国することが出来なくなった。従って、

40 山崎豊子『大地の子』(三) (文春文庫, 1996), p.35.

41 注39に同じ, p.199.

42 中野謙二『中国残留孤児問題一その問いかけるもの一』(情報企画出版, 1987), pp.88-90. 
陸一心は周囲の中国人に敵視される環境の中で、生きざるを得ない。生き残るために は、中国人の仲間に入らなければならないのである。だが、単援朝(2018)は当時の、中 国の国情を踏まえ、残留孤児の生活環境について、次のように記している。

1950 1970年代の中国においては朝鮮戦争、台湾問題、ベトナム戦争などがあっ て、愛国主義教育は反米を中心に展開してきたからである。従って、日本人残留孤 児に対して、小説に描かれているほど周囲が敵視したことは考えられにくい 43 。

しかし、中野謙二(1987)は、中国残留孤児の生活状況を次のように記している。

周辺から「小日本鬼」といじめられて育った者が多い。憎い日本の子供、あるいは この日本野郎と罵倒する意味あいである。新中国が日本軍国主義批判の教育を進めた のだから、身近にいる日本人が批判の対象とされる(後略 $)^{44}$

そのほか、中国残留孤児へのインタビューから、彼らの中国で差別された苦しい経 験が読み取れる ${ }^{45}$ 。単援朝の見方と違い、中国残留孤児は実際に、周りに敵視されてい たことがわかる。特に、「日本軍国主義批判の教育」は、小説でも描かれた。山崎は【表 2】で示した中国歴史教科書の内容を引用し、主人公が歴史の授業を受けた場面を描い た。その場面は次のように表現された。

「第一次世界大戦後、日本帝国主義は野心満々、中国を日本一国で独占し、植民地 に変えようとしたのです、(中略)一九三一年九月十八日、中国東北境内に駐屯した日 本侵略軍は潘陽を攻撃したのです」

\section{(中略)}

その授業があってから、一心に白い眼が向けられるようになった。隣席の姚は一 言も口をきかず、寮でも十一人の同室者がよそよそしくなり、腹を膨らませて殺し た蛙や、使い古した剃刀が布団の中に入饥てあり、小学校時代のように小日本鬼子 と雎し立てない代りに、陰湿ないじめ方をした ${ }^{46}$ 。

歴史的事実としてあるように、日本軍国主義批判教育を進めた新中国で、陸一心は周 囲に敵視され、排除されている。被差別の状況を変えるには、自分が中国人だと証明し なければならない。何故ならば、日本に戻ることは不可能だからである。中国人として 生きるほかはない。中国人となる限り、中国残留孤児のレッテルを外すことで、平等に

43 単援朝「日中女性作家が描いた中国残留孤児像：山崎豊子『大地の子』と厳歌苓『小姨多鶴』を読む」(『跨境/日 本語文学研究』第6号, 高麗大学校GLOBAL日本研究院, 2018.6), p.40.

44 注42に同じ, p.91.

45 張嵐「『中国残留孤児』の社会学一日本と中国を生きる三世代のライフストーリ一」(青弓社, 2011), pp.173-191.

46 山崎豊子『大地の子』(一) (文春文庫。 1996), pp.22-23. 
扱われると主人公は思い込んだ。

さて、では、どのように、陸一心は自分が中国人であることを証明できるのか。共 産党の青年組織一共青団に加入することによって、それを証明しようと考える。

十五歳以上になると、入団資格が出来る。(中略)身体健康、学業良好、政治思想 堅固の“三好”学生はほとんど入団できた。一心は、三好のいずれの資格も備えていな がら、何度、申請しても、入団出来なかった。

(中略)

その三力月後、卒業直前に共青団入団の許可がおり、一心はようやく一人前の中 国人民として認められて晴れ晴れとした感慨にひたった ${ }^{47} 。$

陸一心は「三好学生」しか加入できない共青団に入団することが中国人となる方法だと 考えた。普通の中国人であることよりも、社会主義新中国に対する敬愛を示す形をとる ことで、中国人として認められると考えたのである。マイノリティとしての戦争孤児 は主流社会に加入するために、主流社会のアイデンティティを受け入れなければならな い。

だが、大学卒業後、就職したばかりの主人公は文化大革命の嵐に巻き込まれ、日本人 であるが故に、冤罪を被り、運命に翻弄された。そして、やっとの思いで冤罪を晴ら し、職場に復帰したところに、日中国交の正常化が訪れた。国交回復の新聞記事を読ん だ主人公の心境は次のようになる。

一心は、日本の総理大臣一行の顔を凝視した。幼い時から、小日本鬼子と苛めぬ かれ、文化大革命が始まると、いち早く、日本特務の容疑をきせられ、日本人なる が故に、常に茂視の対象とされてきたが、これから同じ中国人として平等に扱われ るのだろうか ${ }^{48}$ 。

主人公の心境について、単援朝は「国交回復にあたって彼が秘かに願っているのは、 皮肉にも日本人ではなく、『中国人として平等に扱われる』ことである。」 た。日中国交正常化が実現してもなお、陸一心は中国人であろうとする。こうして、陸 一心の中国人としてのアイデンティティ意識が根強く脳裏に定着されたと分かる。作品 を通して、1958年長崎国旗事件後、両国の交流が断絶された後、残留孤児の立場がどれ くらい険しいのかが読み取れる。

日中国交回復後、間もなく、両国合作の製鉄所建設は進められた。上役は日本語に堪 能な陸一心がこれからの日中ビジネス交渉で重要な役割を果たせると感じ、彼を抜擢

47 同上, pp.179-185.

48 山崎豊子『大地の子』(二)（文春文庫，1996）, p.67.

49 単援朝「日中女性作家が描いた中国残留孤児像：山崎豊子『大地の子』と厳歌苓『小姨多鶴』を読む」(『跨境/ 日 本語文学研究』第6号, 高麗大学校GLOBAL日本研究院, 2018.6), p.39. 
し、入党をも勧めた。

「ところで、前から考えていたんだが、そろそろ、君も入党の申請をしては?」

(中略)一心は、言葉に詰まった。

党員になることは、名実ともに選ばれた中国人として認められる栄誉あることで あった ${ }^{50}$ 。

入党は陸一心の長年の宿願である。だが、党員となることは同時に、中国人として 認められることを意味するのか。上役の真意は次のようになる。

陸同志、もし君が入党したら、我らの偉大な社会主義祖国一一中国を、今まで以 上に熱愛し、いかなる場合においても、中国人民の利益を最優先させ就ばならな いそそのところの認識は、きちんとできているのか权?

我らの中国一、その言葉は、一心の出自である日本人の血を指した差別の言葉に 他ならない。

だが、宣誓をし、重工業部の全党員と一緒にインタナショナルを歌っているうち に、一心の屈辱も消え、宣誓通り、今後の人生を迷わず、党と国家に捧げようとい う気概にみち溢れ、感動していた ${ }^{51}$ 。

「我らの中国」といら一言から見ると、陸一心を入党させるのは、彼を中国人として 受け入れることではなく、日中交渉において、日本語に堪能な彼に重要な役割を果たさ せるために、丸め込む手段だと読み取れる。

また、「党と国家」といら言葉に注意したい。前文で述べられた引用で、「日本のスパ イ」と疑われ、批判された主人公が弁明した時、「党と国家」に云い及んだ。ここで、再 び「党と国家」が現れた。新中国成立後、「党と国家」は中国の政治用語として、多くの場 面で使われていた。「党と国家」だけではなく、「党と政府」、「党と人民」も新聞記事、政 府公文、国家指導者談話に常に現れる ${ }^{52}$ 。「党と国家」とは、党と国家は一体であり、分 けられないということである。「党と政府」「党と人民」同じ解釈である。

それで、党と国家が一体であれば、党組織に受け入れられれば、中国人としても認 められると陸一心は考えた。主人公の考えの裏には、「共産党員＝中国人」という認識が

50 山崎豊子『大地の子』(二) (文春文庫, 1996), pp.291-292.

51 山崎豊子『大地の子』(三) (文春文庫, 1996), pp.150-151.

52 その三つの言葉表現として、「党政治局で機関決定したもので、党と国家の指導制度の歴史的歩みを総括 し、なぜ、いま改革が必要なのかを提起したものだ」(「トウ氏 80 年演説が政治改革の綱領？人民日報など 一斉に再発表」『朝日新聞』1987年7月2日．朝刊．1外面．7頁）、「什年余の革命の生涯で、共産主義の理想 を断固として守り、党と人民に無限の忠誠を尽くした模範といえる』と評し、(中略)陳氏を党員の理想像 として学ぶよう求めた。」(「陳雲氏に高い評価 中国政府が死去を公式発表、朝日新聞』1995年4月12日，朝 刊, 3総面, 3頁)、「党の報道機関の主要言論、国内外に関する主要報道は、党と政府を代表するもので、編 集者、記者個人を代表するものでない。」(「中国に民間紙不要 胡総書記が社会主義報道で見解 マスコミ自 由化にクギ」『朝日新聞』1985年4月15日. 朝刊. 3総面. 3頁)などが挙げられる。 
潜んでいることが分かる。

だが、製鉄所建設途中、両国の間で、亀裂が生じ、互いを猜疑した際、主人公は、再 び日本人であるが故に、機密漏洩の嫌疑をかけられ、左遷された。その結果から見る と、入党すれば、中国人として認められるという考えは主人公の空想に過ぎない。当時 の日中関係の側面には、翻弄された主人公の姿がある。1985年、山崎が訪中取材の二年 目、中曽根首相の靖国参拝問題は当時の日中関係に大きな波紋を投じた。

夏頃から始まっていた学生の反日運動は、九月十八日、天安門広場に「日本軍国主 義打倒」中曾根打倒」靖国神社参拝反対」のスローガンを掲げた反日デモを皮切り に、西安、武漢にまで拡がって行った。(中略)靖国問題に端を発した反日感情は、中 国の首脳者だけでなく、一般人民にまで及んでいることを痛感した ${ }^{53}$ 。

1985年12月7日、胡耀邦との二回目の会談で、山崎は中国の靖国批判について言及し た。胡耀邦は次のように答えた。

決して日本の内政干渉をしているわけではなく、もっと中国人民の感情を傷つけ ぬよう配慮して貪いたい、中国は八力国侵略(中略)を受けてから八十五年経って、 ようやくその記憶が薄れて来たが、抗日運動からは四十五年、中日戦争からはまだ 四十年しか経っていない54。(後略)

そのため、国交正常化後、「日中友好」の言葉が揭げられたとはいえ、日中戦争の恨み と確執を容易に帳消しにすることはできないと山崎は感じ取った。そして、両国間の不 和をも作品に書き込んだ。陸一心が左遷されたタイミングは、ちょうど製鉄所建設竣工 直前の1985年に当る。それは、中曾根首相の靖国参拝時期と重なり、日中関係が一時冷 え込んできた頃である。主人公がこのような日中関係に翻弄された様を作中で描いてい るのである。

\section{2 日本に対する認識}

前節では、主人公のアイデンティティ意識を分析した。ただし、中国人になりたい と考える主人公は日本、或いは日本人同士に対し、どのように思ったのか。文革直後、 冤罪を晴らし、職場に復帰して間もなく、主人公は日本の鉄鋼業訪中団を接待するよう と命じられた。このシーンにおいて、一つの意味深い場面が次のように描かれた。

「ご覧のように上吹き酸素式で、中国ではじめて設計、製造、据え付けを行った

53 山崎豊子「『大地の子』と私」(文春文庫, 2003) , pp.94-95.

54 同上, p.107. 
転炉です。」

副経理は胸をそらせて、説明したが、製鋼のための上吹き方式は、日本では以前 から、ごく一般的に行われていたから関心を持たなかった。それより、(中略)転炉 自体の規模の小ささにも驚いた。わずか三十トンの転炉は、日本の十分の一の規模 であった。

(中略)一番うしろから遅れて歩いている二人の団員は、三十トン転炉に眼をや り、日本語が解る作業員などいるはずがないと思ったらしく、

「遅れているな、玩具みたいだな」

と囁き合った。その途端、転炉の近くで、喰い入るように一行の一挙手一投足を 凝視していた若い工程師(引用者注：陸一心)の顔が動き、両手の拳をぐいと、握りし めたことには、気付かなかった ${ }^{55}$ 。

これは、主人公が日本鉄鋼業視察団を接待する場面である。中国の遅れた製鋼設備を 見、二人の日本人は秘かに中国の技術の遅れを揶揄した。主人公は二人の私語を聞き取 り、プライドが傷つき、憤っている。その「玩具みたい」な転炉は、「世界各国の研究論 文、設備技術書を夜を徹して読み漁り、討論し合い、実験に実験を重ねて、造り上げた 一心たちの精魂を傾けた」ものである。だが、「玩具みたいだな」と挪揄され、主人公の 「の胸に、鋭く突き刺さった。」 ${ }^{56}$ 日本の製鋼技術と比べ、中国のほうが遅れていると自 覚したが、自分が作ったものが日本人に挪揄され、やはり、怒りを抑えきれない。主人 公の心理描写は以下のようになる。

一体、あの日本人たちの精神構造は、どのように成り立っているのだろうか。曾 て武力を以て中国大陸を侵略し、無辜の人民まで殺戴しておきながら、国交回復で は『遺憾』という曖昧な表現で、過去の罪業を詫びたのみであった。自分はその世代 の日本人たちの犯した過去の罪悪に、幼い頃から小日本鬼子と軽䟠され、絶えず、 頭を垂れて生きて来たのだった。

(中略)彼ら日本人には一片の贖罪感も見受けられない。国交回復で、すべてが清 算されたかのように尊大で、優越感さえ見られる。そして製鋼視察団の一行の二人 の団員は、「遅れているな、玩具のようだ」と私語し、中国の製鉄状況を侮辱する言 葉を吐いたのだった。何という無神経さであろうか 57 。

以上のように、主人公の最初の対日感情が描かれた。一番目の段落は、主人公が中国 残留孤児の立場に立ち、日本の中国侵略、及び彼ら残留孤児を見捨てたことへの訴えで ある。二番目の段落は逆に中国人の視点から、日本視察団員の傲慢さへの批判である。 ここで、特筆したいのは、「『遺憾』といら曖昧な表現」である。その出典は1972年9月25

55 山崎豊子『大地の子』（二）(文春文庫, 1996), p.91.

56 同上, pp.91-92.

57 同上, p.95. 
日、田中首相訪中期間の演説である。

田中演説の中で、過去の侵略戦争に関して「過去数十年にわたって、日中関係は遺

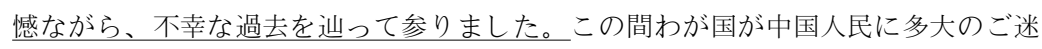
惑をおかけしたことについて、私は改めて深い反省の念を表明するものであります」 と述べたが、この「多大のご迷惑という表現が、中国側で問題となったのである。

(中略)侵略戦争に対するけじめの問題は、日本側が考えるより以上に、中国側に とっては重大関心事であり、敏感であった ${ }^{58}$ 。

日中国交回復の際、田中首相の「迷惑」発言は中国で一時取り沙汰された。「迷惑」とい う言葉は中国語の「麻煩」と等しく、「すみません」という軽い謝りの意味である。ゆえ に、田中首相の謝罪は誠意がないと中国人に受け取られた。小説の中で、陸一心は中国 人の立場に立ち、当時、中国人の日本への不信感を代弁した。また、陸一心は自身の苦 難を日本の中国侵略のせいにし、日本を恨んでいた。だが、その恨みは、主人公の日本 に対する理解が深くなるにつれ、別の感情に転化した。

日本に来、客観的にその優秀さに触れるにつれ、これまで牢固として抱き続けて いた日本に対する反撥、恨みが徐々に薄れ、何となく愛着のようなものを感じて来 る。(中略)旦本の先進的工業力に惹きつけられたが、それにも増して一心の心を惹 いたのは、日本の農家、田畑の光景であった。中国の田畑は、ずっと地平線まで延 びて宏大であるのに対して、日本の田畑は後ろにすぐ山があり、視野を遮る狭さで あるが、そのなだらかな山の形が、一心の心を和ませた ${ }^{59}$ 。

日本に出張中、陸一心は日本の工業力に魅了され、日本への印象が益々よくなってき た。さらに、中国東北平原の田畑風景と比べて、陸一心は日本の風景を好むようにな る。日本の風景を目の当たりにし、親近感を覚えるようにさえなってきた。さらに、母 国に対する帰属感があるのか、次の引用文からは主人公の日本への愛着が感じられる。

\footnotetext{
(陸一心は) 日本へ着いてから、自分の日本に対する感じ方、徐々に変わりつつあ ることに気付いていた。

小学校時代からの思想教育で、日本人であることは䎵ずべきことと教えられてい たが、敗戦後、僅か三十四年間に、奇蹟ともいうべき復興を遂げた日本人の努力と 知識は、公平に見て、尊敬に値する一 (中略)

「こんな進んだ日本を見ると、さすが複雑な心境じやありませんかね权え 「何のことだね、私は中国人だ」 60
}

58 古川万太郎著『日中戦後関係史』(原書房, 1981), p.388.

59 山崎豊子『大地の子』(三) (文春文庫, 1996), pp.35-36.

60 同上, pp.33-34. 
出張をきっかけにし、日本の風土を感じ取り、母国に愛着を抱き始めた。その上、 敗戦後の復興を遂げた日本人の努力と知識に感心し、中国人としてのアイデンティティ 意識が少し摇らいできた。日本を見杖、心境が複雑になってきたのではないかという 同僚の質問に対し、自分は中国人だと主張し、自己のアイデンティティを再確認した。 だが、母国への思いは容易に抑圧されるものではない。日本人実父と再会した際、陸一 心は自分の出自を考え直した。

日本名、松本勝男、松本耕次の長男として長野県信濃村で生まれた一、これが自 分の出自であったのだ。(中略)一心の胸に、三十八年を経て、はじめて実の父と相 会うことが出来た喜びが涌いて来た。

(中略)しかし同時に、父の現在の立場を考え、国家的プロジェクトである宝華製 鉄建設指揮部における自分の立場を考える時、素直に喜べぬものがあった ${ }^{61}$ 。

せっかく実父と再会し、記憶喪失で忘れていた日本名と出自を思い出したが、父と自 分の立場を配慮し、率直に喜ぶことはできなかった。その心理描写から、陸一心の内面 における中国と日本の狭間で囚われた葛藤が読み取れる。若い頃、中国に忠誠を尽くし ても、中国人としては認められなかった。中年になって、日本の風景を感じ取り、実父 と巡り会い、日本人としての記憶を取り戻したが、素直に日本人となることはできな い。陸一心はこのようなアイデンティティ・クライシスから抜けられないのである。

\section{3 まとめ}

本章は主人公の心理描写と行動を辿りながら、中国人となる宿願、母国日本に対する 認識を考察した。陸一心は、幼い時から、両国の狭間で、残留孤児の宿命を背負わざる を得なかった。被差別の状況を変えるために、陸一心は積極的に共青団、共産党に加入 し、党と国家に忠誠を尽くせば、中国人として認められると信じていた。しかし、幾度 も複雑な日中関係に翻弄され、彼の宿願は実らなかった。

一方、陸一心は中国を侵略し、戦争孤児を見捨てた日本を恨んでいた。だが、日本出 張を機に、母国の自然を感じて、日本の戦後復興を知り、中国人としてのアイデンティ ティが摇らいできた。実父と再会し、忘れていた自身の日本名と出自を獲得したとはい え、自分が中国政府の官僚であるという立場を考えると、日本人になろうと決意するこ とはできない。

つまり、陸一心は完全な形では、中国人にも、日本人にもなれない。両国の間で挟 まれ、精神上の苦痛に耐えている。だが、結末で、彼は遂にその苦痛から解放された。 その点について、次章で論じる。

61 山崎豊子『大地の子』(四) (文春文庫, 1996), pp.46-47. 


\section{4 なぜ、「大地の子」と自称したのか}

結末で、主人公は再度冤罪を晴らした。一方、製鉄所建設も一段落した。主人公は日 本人実父と長江へ旅をする。途中、実父は息子に帰国しようと勧めた。陸一心は「日本へ 帰って日本人として生きるべきか、このまま中国に留まって中国人として生きぬくべき か。」 ${ }^{62}$ と思い乱机た。だが、船が長江三峡から出て、両岸の雄大な自然風景を目の当 たりにし、ようやく答えを見つけるのである。

両岸の岩壁はさらに狭まり、きりたった岩山に行手を遮られるかと思った瞬間、 船はぐるりと迴って、波が涌きたつ急流を脱し、あっといら間に峡谷を出た。 そこには天空が展け、壮大な大自然が出現した。一心は、その大自然に搏たれ た。

眼前の岩山や緑の峰、河岸の巨大な厳も、すべて自分を育んでくれた中国の大地 に根を下している。そう思うと、河岸の峰々の一木一草が、自分自身に思え、一心 を摇さぶった。

「大地の子……

山頂から吹き渡って来る風に、語尾がかき消された。松本は訝しげに一心を見返 した。

「私は、この大地の子です」

$$
\text { (中略) }
$$

(中略)船は、滔々たる長江を下って行った ${ }^{63}$

主人公は両岸の自然風景を見、自分も眼前の「岩山や緑の峰」「一木一草」のように 「中国の大地」に育てられたと悟り、「大地の子」と自称し、中国に残ろらと決めた。先行 論は「大地の子」という言葉に注目し、その意味を解釈した。単援朝は次のように述べ る。

その裏に養父母への恩返しの気持ちや家族と過ごした中国への愛着などがあると 同時に、「日本人なるが故」という宿命を乗り越えるためでもある。(中略)運命に翻 弄されながら成長し、中国で生きて行こうとする陸一心は山崎豊子が描いた理想的 残留孤児像であり、そこに彼女の戦争への反省と日中友好への願いが込められてい るといえる ${ }^{64}$ 。

単氏は主人公が「大地の子」を自称し、残留孤児の宿命を乗り越えたと指摘した。一

62 同上, p.335.

63 同上, pp.336-337.

64 単援朝「日中女性作家が描いた中国残留孤児像：山崎豊子『大地の子』と厳歌苓『小姨多鶴』を読む」(『跨境/日 本語文学研究』第6号, 高麗大学校GLOBAL日本研究院, 2018.6), p.46. 
方、そこには山崎の戦争反省及び日中友好の願望が含まれていると主張した。しかし、 まず、「日中友好への願い」という解釈に論者は同意しか㸚る。山崎は初めて胡耀邦と会 見した際、「小説はスローガンではありません。私は中日友好のために小説を書くと報 道されていますが、最初からそれを前提にして書くことはできない。書いたものが結 果的に中日友好のためになればと思っています」 ${ }^{65}$ と話した。これに対して、胡耀邦は 「中国を美しく書いてくれなくてもよい。中国の欠点も、暗い影も書いて結構。ただ、 それが真実であるならば」 ${ }^{66}$ と返事をした。このことを鑑みると、山崎は日中友好のた めに、小説を書くはずはないだろう。従って、「日中友好への願いが込められている」 という解釈は不適切である。

そのほか、「『日本人なるが故』の宿命を乗り越えた」という解釈にも疑念を抱く。「大 地の子」と自称し、果して「日本人なるが故」という宿命を乗り越えられるのか。この点 について、後文で検討する。一方、大澤真幸(2017)は「大地」の含意に注目し、

社会的秩序の中で排除されている者、社会の中に安定した居場所を与えられてい ない者、そういう者にあえて同一化し、そのようなあり方こそが「すべて」である (中略)排除されているという事実が、中国人でも日本人でもないという差異性を表 現するからだ。中国人の中の日本人戦争孤児という立場は、このような排除された ポジションの典型である。陸一心は、そのようなポジションを引き受けることで、 「大地(普遍性)の子」となりえているのだ 67 。

と、所謂「大地」が中国残留孤児のような社会的秩序から排除された人の普遍的な居場 所だと分析した。だが、小説の結末における「眼前の岩山や緑の峰、河岸の巨大な㦑 も、すべて自分を育んでくれた中国の大地に根を下している」という一文には、「中国の 大地」と明確に書かれている。つまり、大地は中国の土地と指す。ゆえに、「大地二普遍 な居場所」という解釈は、小説における本来の意味と異なる。「大地二中国」ということ こそ本来の意味である。

ところで、作者は如何に「大地の子」という言葉を作ったのか。まず、結末の出典に 着眼したい。モデルとしての張永海は同じく実父に永住帰国を勧められたが、結局、中 国に戻った ${ }^{68}$ 。作者は張永海の経歴に基づき、結末を着想したと考えられる。また、山 崎の自作解説にも、「大地の子」という言葉の出処が確認できる。出処は次のようにな る。

陸一心が日本人として育ったのは、わずか六歳までで、教育を受け、結婚をして

65 山崎豊子「『大地の子』と私」(文春文庫, 2003), p.18.

66 同上, p.18.

67 大澤真幸『山崎豊子と〈男〉たち』(新潮新書, 2017), p.171。

68 注65に同じ, p.44. 
子供を持ったのは中国の大地ですからね。私も新疆自治区のソ連国境に近いところ までずっと歩いてみて、ものすごい大地だと思いましたから、やはり、「私は、こ の大地の子です」と言うしかなかったですね ${ }^{69}$ 。

以上のように、山崎は主人公が「大地の子」と叫ぶ結末を考え出した。さて、陸一心は 何故、「大地の子」と自称したのか。そもそも、陸一心の目的は「残留孤児」のレッテルを 外し、翻弄された運命から脱出することである。中国人となるということは主人公の苦 難な運命から抜け出す手段である。

陸一心は最初から、党と国家に忠誠を尽くせば、中国人として認められると考えて いた。そうすることで、中国残留孤児としての宿命を乗り越えようとしたのである。前 文で提起されたように、その考えの中には、「共産党員＝中国人」という意識が潜む。だ が、日本という出自のせいで、主人公は排除された。

その後、船旅で、自分は草木のように中国の大地に育てられたと主人公は気付い た。中国の大地に育てられた子、即ち「中国の大地の子」であれば、自分は紛れもなく、 中国人になると悟った。「共産党員＝中国人」と異なり、「大地の子＝中国人」という考え は他者の承認を得る必要がない。つまり、自分が中国人であると証明することに苦心す る必要がなくなるのである。こうして陸一心は、「中国残留孤児」のレッテルを外し、 「大地の子」という新しい身分を獲得し、アイデンティティの葛藤から脱却した。

次に、実父が息子の「大地の子」という自己規定を聞いた後の反応を分析したい。実父 の反応は次のようになる。

(1)大地の子一、それは日本の父に対する惜別であり、自分自身の運命に対する無 限の呼びかけに他ならない。松本は発する言葉もなく、河岸に眼を向けた。苜四十 年間、この大地に育ち、生きて来た息子とは、もはや埋めようのない隔たりがある ことを思い知った ${ }^{70}$ 。

まず、傍線部1に注目したい。「日本の父に対する惜別」とは、実父への別れを意味 するのみならず、日本人としてのアイデンティティを放棄するということである。「自 分自身の運命に対する呼びかけ」に至っては、「大地の子」という身分を自分自身に授 け、「中国残留孤児」の運命を離脱しようという願望が含まれると思われる。そして、傍 線部(2)、実父の心理描写である。彼は、息子と既に四十年間切り離され、二人の間で は、埋められない深い溝があると悟り、息子の選択を尊重した。

最後、単氏の「『日本人なるが故』の宿命を乗り越えた」という解釈に戻りたい。「大地 の子」と自称した後、翻弄された運命から脱出できるのか。やはり、主人公の人生がこ のあと楽になり、苦難がないとは考え難い。では、主人公にとって、「大地の子」という

69 山崎豊子「伝えること一。それが生き残った私の使命です」(『SOPHIA』, 講談社, 1993.2), p.228 70 山崎豊子『大地の子』(四) (文春文庫. 1996), p.337. 
自称はどのような意義があるのか。結末における長江の旅の隠喻性から、その意義を解 䣋したい。長江三峡(㫿塘峡、巫峡、西陵峡)における川筋は湾曲し、水の流れも激し い。これは、「自分が日本人なのか。中国人なのか」といらアイデンティティの葛藤に乱 された主人公の心境を示唆する。最後の西陵峡から出た際、長江両岸における景色を 見、自分も河岸の草木、巌のように大地に育てられたと悟り、「大地の子」と自称した。 その時、彼らが乗った船は三峡から出て、視野が広く、水の流机が緩やかな長江中下流 に到達した。それは、主人公の内心は安定し、既に両国に挟まれたジレンマから脱出し たことを暗示する。

\section{5 終わりに}

本稿は主人公が戦争孤児から大地の子となる経緯を検討した。まず、作家の取材活動 記録、参考文献を調查し、陸一心の人間像がどのように造られたのかを明らかにした。 そして、主人公の言動と心理描写を辿り、戦後の日中関係をも視野に入れ、中国に忠誠 を尽くし、周囲に中国人と認めさせようという主人公の試みが失敗した理由を検討し た。検討を通じて、起伏に富んだ日中関係は、中国残留孤児としての主人公の運命に大 きな影響を与え、さらに、彼の中国人となる行動をも挫折させることになると分かっ た。

次に、主人公の母国に対する認識に注目した。小説の内容分析を通じて、出張期間、 母国の自然風土を感じ取り、日本の戦後復興を体感することで、日本へ好感を持つよう になり、中国人としてのアイデンティティが動摇したことを読み取った。しかし、実 父と再会した後、忘れていた日本名と出自を得たにもかかわらず、素直に日本人になる ことを決められなかった。こうして、主人公は未だに両国の間のジレンマで迷ったの である。ただ、これだけでこの作品は終わらない。論者は結末部分にこそ作品の重要な テーマがあると考えた。

そして最後、結末における「大地の子」に焦点を当て、先行論の解釈を踏まえ、文脈を 考察し、主人公が「大地の子」と自称した理由を改めて分析した。分析の結果、船旅で、 主人公は長江両岸の草木を見ながら、自分も草木のように、中国の大地に根を下ろし、 大地に育まれたものであると悟った。従って、日本へ永住帰国を勧める実父の誘いを断 り、中国に残った。こうして、主人公は「大地の子＝中国人」というルートで、中国人と してのアイデンティティを定着させ、遂に「中国残留孤児」といらレッテルを外し、日中 両国に挟まれた葛藤から解放されたのである。本作品の最も重要な点は主人公が自らの 意志で日中両国の板挟みから解放され、アイデンティティ・クライシスから離脱し、人 間らしさを取り戻すことにある。

本研究は主に作者が如何に主人公を造形したのか、及び中国残留孤児である主人公は 
どのようにアイデンティティ・クライシスから離脱したのかを検討した。そして、本 稿で論じなかった主人公と他の登場人物との関係を詳細に考察することを今後の課題と したいのである。

\section{参考文献(Bibliography)}

\section{著作}

新潮社山崎プロジェクト室編 (2015) 『山崎豊子スペシャル・ガイドブック』．東京：新潮社． Shincho Sha Yamasaki Project(2015) Toyoko Yamasaki Special Guidebook.Tokyo : Shincho Sha.

山崎豊子(1996) 『大地の子』(一) (四). 東京：文春文庫. Toyoko, Yamasaki(2003) The Son of Earth (1)- (4). Tokyo : Bunshun Bunko.

山崎豊子(2003) 『大地の子』と私』. 東京：文春文庫. Toyoko, Yamasaki(2003) “The Son of the earth” and Me. Tokyo : Bunshun Bunko.

大澤真幸(2017) 『山崎豊子と侽〉たち』, 東京：新潮新書. Osawa. Masachi(2017) Toyoko Yamasaki and the Men. Tokyo : Shincho Shinsho.

古川万太郎(1981)『日中戦後関係史』, 東京：原書房. Furukawa, Mantaro(1981) Post-War Japan-China relationship, Tokyo : Hara Shobo.

中野謙二(1987)『中国残留孤児問題一その問いかけるもの一』, 東京：情報企画出版. Nakano, Kenii (1987) The problem of residual orphans in China. Tokyo: Joho Kikaku.

張嵐 (2011)『中国残留孤児』の社会学一日本と中国を生きる三世代のライフストーリー』，東京：青弓社， Zhang. Lan(2011) Sociology of Chinese Residual Orphans -The Life Story of Three Generations Living in Japan and China.Tokyo : Seikyu Sha.

辻平治郎 (2003)『自己意識と他者意識』, 京都：北大路書房. Heijiro. Tsuii (2003) Self-Consciousness and Other Consciousness. Kyoto : Kitaoji Shobo.

\section{論文}

王晶·王亭亭 (2015)「山崎豊子筆下的中国東北遺孤一以『大地之子』為中心」『日本研究』2015年第1号. 遼寧大学日 本研究所. pp.84-89. Wang Jin. Wang Tingting(2015) The orphans of Northeast China described by Yamazaki Yuko-centered on The Son of the Earth. Japan Research. 2015 First Issue. Japan Institute of Liaoning University. pp.84-89.

李徳純 (2014)「不譲須眉的日本女作家」『中日関係史研究』2014年第1期. 中国中日関係史学会. pp.65-90. Li Dechun(2014) "A Japanese Woman Writer who are no inferior to men". Research on the History of Sino-Japanese Relations. 2014 First Issue. China Society for the History of Sino-Japanese Relations.pp. pp.65-90.

単援朝 (2018)「日中女性作家が描いた中国残留孤児像：山崎豊子『大地の子』と厳歌苓『小姨多鶴』を読む」『跨境/ 日本語文学研究』第6号, 高麗大学校GLOBAL日本研究院, pp.33-48. Yuanchao. Shan (2018) Depictions of Japanese Children Left Behind in China through the Perspective of Japanese and Chinese Female Writers: Based on Toyoko Yamasakis The Son of Earth and Yan Geling's Auntie Duohe (Tazuru). Crossing : Japanese Literature Studies Vol. 6. Global Institute for Japanese Studies of Korea University, pp.33-48. 朱琳 (2018)「野上孝子氏インタビュー一山崎豊子と『大地の子』—」城西国際大学日本研究センタ一紀要』8号, 
城西国際大学日本研究センター, pp.53-61. Zhulin (2018) “Interview with Takako Nogami-Toyoko Yamazaki and The Son of Earthr". Bulletin of the Japan Research Center, Josai International University. Vol. 8. Japanese Studies Center of Josai International University, pp.53-61.

張賢亮著·大里浩秋訳 (1986)「霊魂と肉体」『中国研究月報』461号、一般社団法人中国研究所. pp.16-37. Zhang. Xianliang · Translated by Hiroaki, Osato(1986) “Ghost and Body". Chinese Research Monthly. Vol. 461. General Incorporated Association China Research Institute, pp.16-37.

\section{雑誌}

山崎豊子(1993)「伝えること一。それが生き残った私の使命です」SOPHAs，講談社、1993年2月, pp.226-240. Toyoko, Yamasaki(1993) Something | Want to Say-This is My Duty. SOPHIA(1993.2). Kodansha. pp.226-240 